\title{
REVALORIZACIJA SEKUNDARNIH PROMETNICA U VELEBITSKOM PODGORJU
}

Ivan Legac

Bednjanska 8

HR 10000 Zagreb

Hrvoje Pilko

Fakultet prometnih znanosti Sveučilišta u Zagrebu

Zavod za cestovni promet

Vukelićeva 4

HR 10000 Zagreb

hpilko@fpz.hr
UDK: 656.1(497.5 Velebit)

Prethodno priopćenje

Ur.: 2016-10-22

Predočeno je opće stanje prometne infrastrukture i prometa u prostoru Velebitskog podgorja, s osvrtom na vremena nastanka povijesnih cesta, putova i staza. Ukazano je na važnije potencijale sekundarnih prometnica, koje bi trebalo vrjednovati u smislu opće ponude Velebita (turizam, sport, edukacijska komponenta...), ali isto tako u pogledu oživljavanja tradicionalnih vidova stvarnog života "in situ". Na tragu ovakvih postavki moglo bi se provesti modeliranje projekata za slučajeve zapuštenih povijesnih cesta (npr. cesta Jablanac - V. Alan - Štirovača, Majstorska cesta Obrovac - M. Alan - Sv. Rok) te projekata sezonsko-migracijskih staza od primorskih naselja do ljetnih stanova na plodnijim velebitskim lokalitetima (npr. staza Klada - Babrovača - Zavižan, Prizna - Mliništa - Šatorina, Cesarica - Radlovac - Dabrovi i sl.). Uz podsustav sekundarnih prometnica problematizirano je također stanje služnosti i sigurnosti prometa na Jadranskoj magistrali (turističkoj cesti) D-8 kao osnovnoj dužobalnoj poveznici Podgorja. Upozoreno je na loše stanje i potrebu što hitnije modernizacije cijele ceste od Senja do Maslenice, te na izvedbu obilaznice oko Sv. Jurja i Karlobaga. Isto tako je potrebno modernizirati poveznice do manjih naselja na obali (Lukovo, D. Klada, Starigrad itd.).

Ključne riječi: povijesne ceste, Velebitsko podgorje, migracijske staze, turistička ponuda, održivi razvoj 


\section{Uvodno o prometu i prometnicama Velebitskog podgorja}

Velebit u širem smislu, sa svojim primorskim pročeljem i s kontinentalnim zaleđem, predstavlja geoprometni fenomen u svojem užem i širem prostoru. Masiv Velebita razdvaja, ali i povezuje Liku, Podgorje i Dalmaciju, što se je odrazilo kroz više povijesnih razdoblja, a na poseban način u rješavanju fenomena tzv. "Ličkog trokuta" u mreži suvremenih autocesta.

U Velebitskom podgorju odnosno primorskoj padini Velebita oduvijek se odvijao određeni oblik prometa, bilo da se je radilo o kopnenom ili pomorskom vidu prijevoza ljudi i roba. Povijesni podaci ukazuju na činjenicu da je pomorski promet oduvijek pratio potrebe lokalnog stanovništva, a u suvremenim uvjetima umnogome povezuje kopnene i otočne prometnice, bilo trajektima (Jablanac/Stinica - Mišnjak, Prizna - Žigljen) bilo mostovnim građevinama (otoci Krk i Pag).

U analizi suvremene cestovne mreže može se potvrditi definiranost primarnih prometnica, a bitnija dopuna treba se desiti na segment autocesta od Vinodola do Žute Lokve. Postojeća Jadranska turistička cesta D-8 duž Podgorja dostatna je za servisiranje potreba stanovništva i trajektnog prometa, pri čemu su opravdane primjedbe na sigurnosne komponente duž njezine trase i u prolasku kroz veća naselja (Senj, Sv. Juraj, Karlobag).

U pogledu mreže sekundarnih prometnica (lokalne i nerazvrstane ceste, putovi i staze) veće su nejasnoće, ali i veći potencijali razvoja u okviru Parka prirode Velebit. S tim u vezi potrebno je učiniti određenu "inventarizaciju" te uz pomoć relevantne metodologije i vrjednovanja prijeći na revalorizaciju zapuštenih tradicijskih vrjednota.

Zadaća inicijalnih istraživanja jest u uočavanju stanja i potencijala pojedinih povijesnih cesta, staza ili lokaliteta te u objektivnoj procjeni ulaganja u njihovu obnovu. U cijelom postupku analiziranja i vrjednovanja trebalo bi uzeti u obzir određene rizike, ali isto tako bitne činjenice koje bi ohrabrile inicijalne čimbenike: prometnice - unikatne povijesne građevine, visok stupanj zainteresiranosti ulagača/domaćeg čovjeka te velika vjerojatnost financijske podrške (PP Velebit, EU fondovi). Za provjeru predloženih postupaka trebale bi poslužiti neke povijesne ceste (npr. Jablanac - V. Alan - Štirovača, Obrovac - M. Alan - Sv. Rok...) i sezonske migracijske staze od sela do stanova na Velebitu (npr. Klada - Zavižan, Prizna - Mliništa, Cesarica - Radlovac itd.). Projekte bi trebalo savjesno i multidisciplinarno koncipirati, u što bi, osim projektanata, bilo neophodno uključiti domicilne ljude i ambijentalne vrjednote te odgovarajuće eksperte za razvoj sličnih oblika turističke ponude. 


\section{Povijesni razvoj kopnene infrastrukture}

Pregled i analiza prometnog sustava može se razmatrati s više stajališta: u pogledu tematsko-tehnološkog razvoja (od staza i putova do autocesta), u kvalitativnom smislu po povijesno-vremenskim horizontima, po prometnim i tehničkim standardima (primarna i sekundarna mreža), po odnosu prema masivu Velebita (longitudinalni i transverzalni smjerovi) te konačno u smislu funkcionalne klasifikacije (javne - državne/županijske/lokalne ceste, te nerazvrstane prometnice - sporedne ceste, putovi i staze).

U pogledu povijesnog razvoja cestogradnje, skromni tragovi ukazuju da su prve ugažene staze postojale već u neolitiku, a posljedično na razmjenu roba slijedili su karavanski putovi između Like i Primorja. Intenzivnije komunikacije preko velebitskih prijevoja posebno su razvili Japodi i Liburni, što su zbog toga izvodili sve bolje putove ili staze. Uz tradicionalnu razmjenu roba i dobara, iste prometnice su služile i za sezonske dolaske stoke na planinske ispaše i za sve cikluse sezonskih migracija stanovništva.

Rimsko imperijalno razdoblje u ovim krajevima datira od zadnjih desetljeća stare ere, tj. od zabilježene vojne mladog Oktavijana, kad se iskrcao u Senju te se sa svojim legijama zadržao u Segesti da uguši pobunu Ilira. Završno gušenje pobune od 6. do 9. godine koincidira s uspostavljanjem povijesne provincije Illirycum/Dalmatia na prostoru Like/Podgorja/Dalmacije.

Upravo zbog izvrsnog geoprometnog i vojno-strateškog položaja između primorskog i kontinentalnog prostora Rimljani počinju graditi prve vojne ceste s čvrstim kamenim kolnikom i dobro trasiranim prometno-tehničkim elementima.

Prema relevantnoj karti iz toga razdoblja (Tabula Peutingeriana) vidljivo je pružanje bitne rimske ceste iz Akvileje za provincije Dalmaciju i Panoniju: preko Trsata (Tarsatica) i Bakarca te Crikvenice (Ad Turres) do Senja (Senia), a onda se izdizala od mora prema Lici (Žuta Lokva, Brlog/Avendona). Izbor rimskih stratega za trasu uzdužobalne ceste preko Senjskih vrata/Žute Lokve i preko Like (a ne preko podvelebitske padine) indikativan je već u ovom slučaju. Indikativan je sličan izbor austrijskih i francuskih vojnih inženjerea u XVIII. i XIX. stoljeća te konačno pri izboru trase autoceste krajem prošlog stoljeća (Sl. 1).

Preostaje pitanje: kako se rješavala komunikacija između manjih podgorskih naselja i luka (Sv. Juraj - Lukovo - Klada - Starigrad - Stinica Jablanac - Prizna - Cesarica). Duboke vododerine i strme uvale prekidale su normalnu komunikaciju, pa su se lokalna povezivanja ostvarivala skromnijim putovima i stazama od kuće do kuće i sl. 


\section{Srednji vijek i razdoblje Vojne krajine}

Propašću Rimskog carstva u 5. i 6. stoljeću propadaju i rimske ceste kojima se još služe novi došljaci - Avari i Slaveni na svom putu prema Jadranu. Slično Japodima i Liburnima, novo stanovništvo je više stočarsko, a manje ratarsko, pa im ceste i staze također u mnogome služe u polunomadskom privređivanju i u korištenju ispaše na velebitskim proplancima. U mladoj hrvatskoj državi razvijaju se određeni duhovni i gospodarski centri (Vrana/Biograd, Nin, Modruš), pri čemu jačaju i određene velikaške obitelji (Frankopani, Šubići i dr.). U vremenima mira i gospodarskog razvoja posebno prosperira grad Senj, koji od 12. i 13. stoljeća postaje središte biskupije i priznato sjevernojadransko trgovačko središte odnosno križišna točka cestovnog pravca preko Senjskih vrata, Brinja i Modruša prema unutrašnjosti ${ }^{1}$.

U razdoblju 12. i 13. st. razvijaju se u podvelebitskom primorju još neka mjesta i manja lučka središta: Sv. Juraj, Jablanac i Karlobag (Oppidum Scrissi), a na putu u Liku naselje Krasno Polje i Otočac. Važna prometnica u to doba bio je karavanski put Senj - Žuta Lokva - Korenica - Bihać/Ključ - Jajce -Travnik, koja je bila pod kontrolom najjačih feudalnih porodica i budimskog dvora (15. st.). Robu u prijevozu činilo je ponajviše drvo, žito, sol, neke kovine, ulje, tkanine i ostalo.

Osmanlijska ugroza iza 15.st. i destruktivni prodori (okolica Senja 1454.g, 1469. grad Senj i Karlobag 1525., Jablanac 1526.) izravno su uzrokovali bijeg stanovništva i postupnu depopulaciju cijelog Podgorja i Like kroz dugo vrijeme. Tek nakon vojnog preuređenja Vojne krajine 1577., a naročito iza poraza Turaka pod Siskom 1593. godine dolazi do svojevrsne vojne ravnoteže na terenu te stabiliziranja vojnih utvrda i izvjesne normalizacije civilnog života ${ }^{2}$.

Nakon ratova (Beč 1683 - 1699) i mira u Sremskim Karlovcima (1694.) Otomansko carstvo je definitivno prešlo u defanzivno stanje, pa je Monarhija i Vojna Krajina mogla početi planirati razvojne projekte. Na kapitalnoj karti P. R Vitezovića iz tog vremena još su ubilježeni postojeći putovi:

- Senj-Vratnik - Brinje

- Ž. Lokva - Otočac - Perušić - Gračac (Lička podužna cesta)

- Karlobag - Oštarije - Novi Lički /Gospić ( - Bihać)

- Obrovac-M. Alan - Sv. Rok - Stari Lovinac

${ }^{1}$ D. PEJNOVIĆ - B.VUJASINOVIĆ, 1998.

${ }^{2}$ Š. BALEN, 1979. 
Podužna podgorska prometnica ispod Velebita nije registrirana, a od prometnica postojale su međusobno spojene od lučice do lučice, između podgorskih "podova" te tzv. vlake od mjesta oborenih stabala na Velebitu do utovara na brodove u lukama. Relativno slabiji povratak stanovništva i sve veće doseljavanje iz područja Ravnih kotara te posljedičnost svih promjena najdramatičniji su se odrazili na Bag/Karlobag. Njega su 1525. razorili Osmanalije, a 1616. godine Mlečani pa je stanje s popunom stanovništva sporo išlo; tek su glavnina zgrada i luka izgrađeni oko 1711. godine pa je novi $\mathrm{Karlobag}^{3}$ postao nezaobilazna luka i ishodišna točka u prometovanju između Srednjeg Podgorja i Like ${ }^{4}$.

Prva prometnica za Liku bila je ustvari nesigurna karavanska staza preko Starih vrata, pa se u vremenu 1730. - 1735. godine izgradila cesta preko poznatog Oštarijskog prijevoja (Stara Karolina), koja ujedno predstavlja prvu vojnokrajišku cestu preko Velebita. Zbog loših elemenata trase i upitne izvedbe učinjene su radikalne rekonstrukcije (1750. - 1754.) što ju je činilo suvremenijom poveznicom primorskog Karlobaga i novog grada Gospića (utemeljenog 30-ih godina 18. stoljeća).

Iduća ubrzana izgradnja cesta preko Velebita bila je najčešće gospodarski opravdana, ali katkad i nepromišljena i isforsirana (npr. slučaj Karoline i Jozefine, napušteni projekt plovnog puta Kupa - Jadran itd). S tehničke i tehnološke strane, međutim, ove su ceste bile odista suvremene i na ponos graditelja u širim europskim relacijama.

Jozefina između Karlovca i Senja bila je ekonomski opravdana (žito, šume, primorski proizvodi, putničko-poštanske potrebe), a izvedena je 1775 1779. godine (počeo pok. Tasse, završio puk. Vinko Struppi). U eksploataciji se pokazala vrlo rentabilnom: premda se teretni promet odvijao zaprežnim kolima, već se je 1782. godine ovom cestom prevezlo i oko 1500 t žita (uz pomoć stotinjak natovarenih kola), pa je trebalo izgraditi veće skladište i rekonstruirati lučka postrojenja (projektant Filip Vukasović). Zbog izrazitog porasta lučko trgovačkih sadržaja Senj je dobio status slobodne luke, a od 1786. godine duž Jozefine uspostavljen je poštanski i putnički promet.

${ }^{3}$ Upravo se u Karlobagu 7. listopada 1759. sastalo povjerenstvo pod predsjedanjem generala Petazzija, koje je odlučilo da se odmah započne s pripremama za izgradnju cesta, i to po projektima i kartama inženjerskog kapetana, baruna Antuna Schredinga. General Patazzi je 1. rujna 1762. naredio pukovniku Petru Vukasoviću (ocu kasnijeg graditelja i podmaršala Filipa Vukasovića) da probije put od Brinja preko Škamnice do Brloga, u namjeri da bolje poveže Liku s budućom cestom Karlovac - Senj.

${ }^{4}$ D. PEJNOVIĆ - B.VUJASINOVIĆ, 1998. 
Filip Vukasović sagradio je između 1783. i 1786. cestovnu poveznicu između Sv. Jurja i Senja. Ubrzo po završetku Jozefine (1785 - 1789. godine) izgrađena je u najvećem opsegu Dalmatinska cesta od Žute Lokve do Otočca, Gospića, Gračaca i Sučevića do tadašnje granice s Dalmacijom.

Zbog prosudbe da Stara Karolina više nije na dostatnom stupnju služnosti, započeta je izgradnja modernije Terezijane (1784 - 1786), kojoj je projektant bio kapetan Filip Vukasović, a Stara Karolina je postupno napuštena ${ }^{5}$.

Razlog za rekonstrukciju Jozefine bio je povećani promet i prevelik nagib trase na dionici Sv. Križ - Vratnik, pa je Filip Vukasović predložio rekonstrukciju, a realizacija poboljšanja provedena je 1787. godine. Sljedeću optimizaciju spriječio je početak ratova s Napoleonom (1805), a izgradnja najsuvremenije Lujzijane (1803 - 1811) i preusmjerenja prometa na Rijeku imali su porazne posljedice za grad i luku Senj.

Prije namjeravane optimizacije Jozefine odlučeno je (1819. g.) da se dade prednost modernijoj longitudinalnoj Dalmatinskoj cesti (Ličko Cerje - Sv. Rok - Mali Alan - Obrovac). Radovi su započeli 1820. od zadarske strane (Zadar Zemunik - Smilčić-Obrovac) u duljini $51 \mathrm{~km}$ trase, na kojoj je otpočela i briljantna karijera graničarskog majora i projektanta/graditelja Josipa Kajetana Knežića. U razdoblju 1827 - 1835. godine izgrađena je slijedeća dionica: Mali Alan - Sv. Rok (duljine $17 \mathrm{~km}$ ), gdje se spajala u postojeću trasu Dalmatinske ceste.

Gradnja cijelog segmenta ove zahtjevne ceste (duljine $24+17 \mathrm{~km}$ ) u cijelosti je završena 1832. godine kad je kao Majstorska cesta svečano puštena u promet (Gospić - Medak - Sveti Rok - Obrovac - Zadar). Naziv "majstorska" u vezi je s terminom Meisterstück i Meisterwerk (tj. završni/majstorski uradak), što je uz mnoge inovacije (razvoj trase, serpentine i tucanički kolnik na složenoj kamenoj podlozi) najpovoljnije ocijenjeno u širim europskim razmjerima. Trasa ceste na izrazito teškom terenu položena je $\mathrm{s}$ uzdužnim nagibom do $5,5 \%$, što je bilo zadržano na duljim potezima (bez "izgubljenih" nagiba) i do danas predstavlja uzorno obavljen projektantski zadatak.

Prateće građevine i uslužni sadržaji i danas potvrđuju svu suvremenost i graditeljsku zrelost majora J. K. Knežića: na Podpragu su podignute javne zgrade (oružana postaja, cestarska kuća sa sobom za putnike, gostionica te crkva i Župni stan). Crkva sv. Franje izgrađena je u čast cara Franje I., a 4 km niže desilo se 4.10.1832. godine u predjelu Meki doci (granica Dalmacije i Austrije) svečano otvorenje ceste ${ }^{6}$.

${ }^{5}$ D. FELETAR, 2003.

${ }^{6}$ Popravak postojeće ceste RC-2820 od Obrovca do Sv. Roka u dužini 9 km, 1998. 


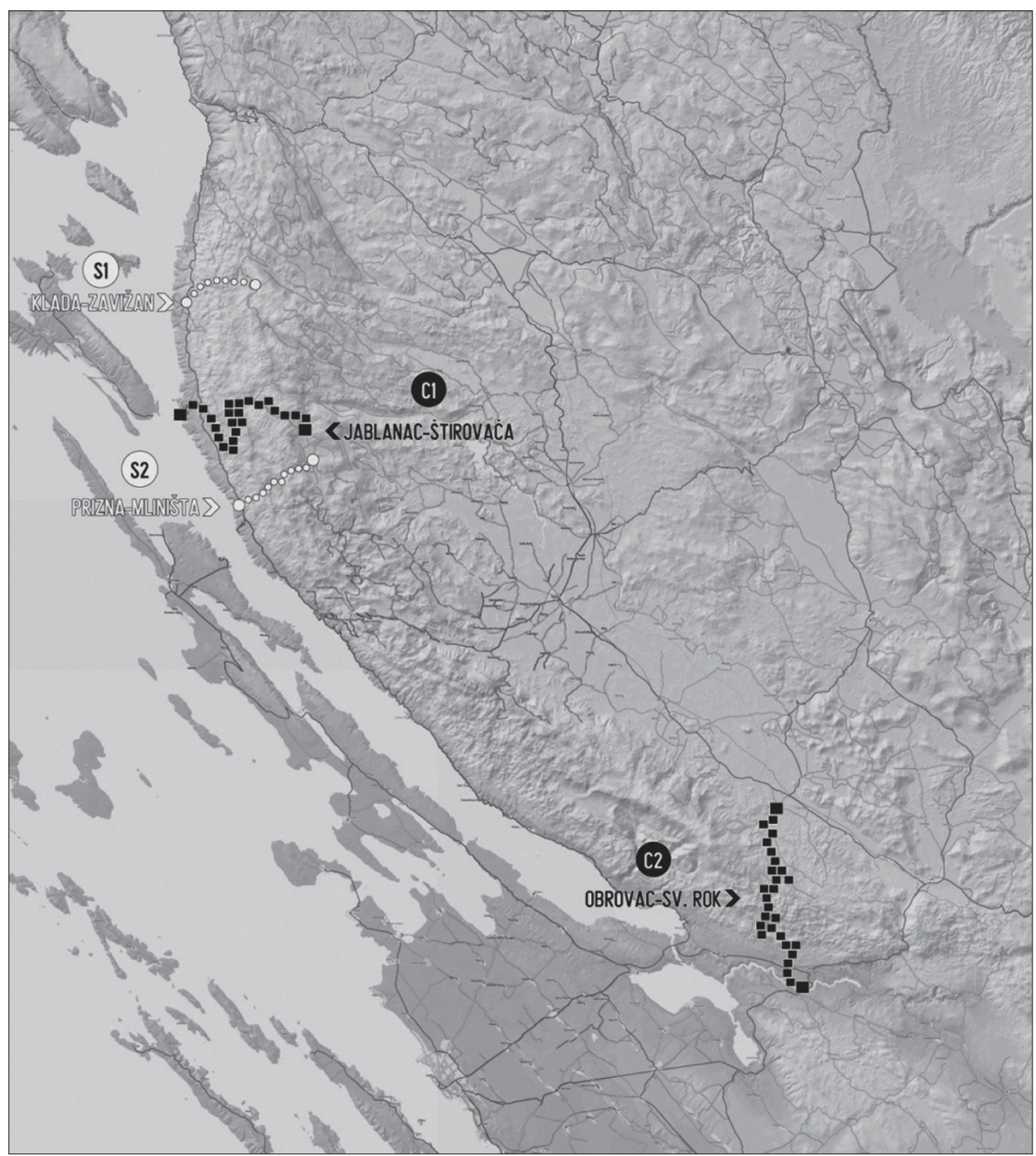

Sl. 1. Dispozicija predmetnih prometnica u Podgorju

Major Knežić je nakon izgradnje Majstorske ceste ubrzano završavao projekt rekonstrukcije Jozefine od Karlovca do Senja, nakon čega su lakšu dionicu Karlovac - Kapela otpočeli 1833. godine a puno teži segment trase Vratnik - Senjska draga izveden je u razdoblju 1836.- 1845. godine. Odlika ove trase su moderno oblikovane serpentine uzdužnog nagiba $6 \%$ (slično kao kod Lujzijane i drugih suvremenih cesta), a cijela Jozefina od Karlovca do 
Senja (duljine $115 \mathrm{~km}$ ) bila je u skladu s onovremenim projektnim elementima i tehnološkim standardima. Treba spomenuti je da je 1830.-1840. godina obavljena temeljita modernizacija Dalmatinske ceste na dijelu Gospić - Gračac - Pađane. Neposredno prije toga (1834.-1835. g.) izgrađena je "tvrda cesta" od N. Vinodolskog do Senja i do Sv. Jurja.

Terezijana između Gospića i Karlobaga je iza toga doživjela i treću rekonstrukciju (1844.-1851. godine), zbog zastarjelih elemenata trase i zbog povećanog prometa, za što je projekte izradio J. K. Knežić. Gradnju zahtjevne dionice od Oštarija do Karlobaga (1846.-1851. g.) vodio je osobno projektant major Josip Kajetan Knežić (u toku čega je i umro 15. rujna 1848. godine u Senju), a gradnju je završio 1851. godine nadareni pomoćnik Simo Kekić. Veliki graditelj J. K. Knežić je pokopan uz trasu Jozefine na lokalitetu Majorija, pri crkvi sv. Mihovila.

Zaključno se mogu potvrditi činjenice o cestama preko/uz masiv Velebita izgrađenim za Vojne krajine u 18. i 19. stoljeću: skoro sve novosagrađene ili modernizirane ceste u području Velebita izgrađene su po suvremenim normativima u pogledu vođenja trase, izvedbe kolničke konstrukcije (širina 4-6 m), odvodnje i prometno-sigurnosnih standarda. Uz vrhunske projektante i tehničko osoblje, posebno treba istaći domaće ljude; klesare, zidare, tesare, priučene poslovođe i ostale majstore u svome poslu. Usporedno s ovim činjenicama nove ceste su donijele neporecive razvojne dobrobiti za stanovništvo uz ceste, ali je ujedno bio i prvi preduvjet za raslojavanje ljudi i društva ${ }^{7}$.

Konačno je 1876. izvedena i brdska cesta preko Velebita (Jablanac Veliki Alan - Štirovača), a 1877. g. i podvelebitska cesta Sv. Juraj - Karlobag kao dugoočekivana poveznica od vitalnog značenja za ovaj dio Velebitskog podgorja.

\section{Podsustav sekundarnih prometnica}

Za razliku od mreže primarnih cesta, odnosno cesta za motorni promet (autoceste, brze ceste, državne i županijske ceste), u predmetnim su analizama razmatrane tvz. sekundarne ceste. U podsustav sekundarnih prometnica uvjetno se mogu postaviti neke lokalne ceste, te sve nerazvrstane prometnice, tj:

- pristupi do naselja

- šumske ceste, putovi i vlake

- staze (svih vrsta)

${ }^{7}$ A. LEMIĆ, 2013. 
Šumske ceste, putovi i vlake gradile su se posljedično na eksploataciju velebitskih šuma i datiraju još od 15.-16. stoljeća (trgovina s Venecijom). Rad sa sječom drveta i s transportom do luka uvodi se tek nakon osnivanja resornih službi u okviru Vojne krajine krajem 18. st., pa se tako za vrijeme Marije Terezije postavljaju stručne službe s odgovornim pojedincima (Franzoni 1764. g., Pierker 1765. g.) koji izrađuju karte i prometnice za potrebe sustavnog gospodarenja šumskim resursima ${ }^{8}$.

$\mathrm{Na}$ osnovi izrađenog plana iz polovice 18. stoljeća, pripremano je više glavnih putova i šumskih vlaka za izvlačenje drvne mase: Štirovača - Jablanac, G. Kosinj - Mirovo/V. Alan - Stinica, D. Kosinj - Krasno Polje - Sv. Juraj, Gacko polje - Vratnik - Senjska Draga. Navedene prometnice predviđene su u širini 1,5 hvata $(2,85 \mathrm{~m})$ i s tlocrtnim zavojima polumjera $\mathrm{R} \geq 25 \mathrm{~m}$ (mjerodavni teret bila je građa duljine $1, \leq 9,5 \mathrm{~m}(5 \mathrm{hv})$. Skladište drvne mase bilo je u Senju i Karlobagu, ali su se do kraja 18. stoljeća odgovarajuća skladišta (depoti) izgradili i u Sv. Jurju, Jablancu, D. Kladi (Velika draga) i Cesarici.

Može se konstatirati da je navedeni program šumskih prometnica u cijelosti realiziran do kraja 19.st., jer to potvrđuju detaljne karte iz početka 20. stoljeća. Zbog Prvog svjetskog rata i zbog duljeg oporavka gospodarstava u tuzemstvu i okolini Senja, u idućim godinama nije bilo osjetnije cestogradnje u Podgorju. Ovakvo stanje je potrajalo i u vremenu do poslije Drugog svjetskog rata, a sav promet odvijao se na mreži šumskih prometnica iz vremena Vojne krajine. Do pred Drugi svjetski rat tako je u srednjem Velebitu održavano svega 50-ak kilometara ovakvih putova (za Baške Oštarije, Jadovno, Klepinu dulibu itd).

Iza Drugog svjetskog rata otpočela je intenzivna eksploatacija šuma na Velebitu, pa je za izvlačenje drvne mase bila potrebna hitna izgradnja šumskih prometnica. Zabilježeni podatci ukazuju da je u vremenu 1948.-1967. g. izgrađeno oko $100 \mathrm{~km}$ u području šumarije Krasno (Tabl. 1.) Tih godina je spojena štirovačka cesta (1959. g.) s veznom cestom Sušanj Cesarički - Ravni Dabar - Položine - Težakovac, a 1965. g. na cestu Vratnik - Klanac te na poprečnu cestu Krasno Polje - Oltari. Duljina ove longitudinalne prometnice od Vratnika do Oštarijskih vrata iznosi $95 \mathrm{~km}$ i od ključnog je značaja za velebitski masiv. Uz bok ove prometnice je tzv. Zavižanska cesta od Sv. Jurja, te preko Oltara i Zavižana do spojnice Krasno Polje - Štirovača, a dionica V. Zavižan (1677 m n.v.) - Pivčevac (1676 m n.v.) s trasom na oko 1540 m n.v. je najviša planinska cesta u Hrvatskoj.

${ }^{8}$ D. PEJNOVIĆ - B.VUJASINOVIĆ, 1998. 
Tablica 1. Pregled šumskih cesta na Sjeveru Velebita, izgrađenih u razdoblju 1950-1970. godine.

\begin{tabular}{|c|l|c|}
\hline $\begin{array}{c}\text { Građeno } \\
\text { godine }\end{array}$ & \multicolumn{1}{|c|}{ Dionica, od - do [km] } & $\begin{array}{c}\text { Duljina } \\
\text { ukupno } \\
\sum[\mathrm{km}]\end{array}$ \\
\hline 1950.-1951. & $\begin{array}{l}\text { Panoga - Lomska duliba (7 km), Ledena draga - Begovača }(6,5 \\
\text { km), Abelovac - Ledena draga (3 km), Oltari - Rakita }(3 \mathrm{~km})\end{array}$ & 19,5 \\
\hline $1948 .-1954$. & Apatišan - Bevandinica (9 km), Klanac - Jagodovac (12 km) & 21 \\
\hline $1955 .-1960$. & $\begin{array}{l}\text { Odvojak za Goljak (3,5 km), Vratnik - Jagodovac, Priključak na } \\
\text { Rajinac, Raskrižje - Krasno (5 km), Klepina duliba - Pložina, } \\
\text { vlaka do Lemić doca (4km) }\end{array}$ & 22 \\
\hline $1961 .-1962$. & $\begin{array}{l}\text { Oltari - Krasanska duliba - Zavižan (16 km), Odvojak za Jezera, } \\
\text { Odvojak za Vučjak (2,5 km) }\end{array}$ & 20 \\
\hline $1955 .-1963$. & $\begin{array}{l}\text { Oltari - Lomska duliba (22 km), Zavižan - Lomska duliba - Spoj } \\
\text { za Krasno, Odvojak za Abez }\end{array}$ & 40 \\
\hline & $\begin{array}{l}\text { Vratnik - Jelovac - Spoj za Krasno (18 km), za Turinski Krč (1,5 } \\
\text { km), Odvojak za Jakovljevu vlaku, Dundović Mirevo - Tuderevo } \\
\text { - V. Lubenovac (6 km), Odvojak do šume Jelovac, Odvojak do } \\
\text { Vranske Drage, dvije vlake u Krasansku dulibu (2,5 km) }\end{array}$ & 35 \\
\hline
\end{tabular}

Staze kao prometnice za pješake (katkad za zaprege i blago) potrebno je shvatiti u vremenskom kontekstu; s njima se prije stizalo do ljetnih stanova, ograda i vlasničkih sjenokoša, a u današnje vrijeme staze i putovi se koriste kao planinarske (ili sportske) prometnice. Od svih njih posebno se ističe Premužićeva staza (građena 1930.-1933. g.) duljine 57 km od Sjevernog do Srednjeg Velebita i na prosječnoj visini oko $1500 \mathrm{~m}$ n.v. ${ }^{9}$

Pristupne prometnice (pristupne ili razvodne ceste) u funkcionalnoj klasifikaciji čine veoma važan segment u svakodnevnom životu domicilnog stanovništva i ostalih korisnika. U klasu pristupnih prometnica ulaze prvenstveno pristupi do naselja i kuća/stanova, te pristupi do luka, lučica i sličnih odredišta. Nastale su na mjestu tradicionalnih staza i putova koji su se po potrebi rekonstruirali i modernizirali za mješoviti promet ili su se pak trasirale nove ceste/putovi u neposrednoj blizini.

U grupu pristupa do naselja i sličnih odredišta mogu se ubrojiti npr. ceste/ putovi do Volarica, G. Klade, V. Brisnice, Sv. Ivana/Prizna, Starčevićeva Poda,

${ }^{9}$ www.velebit.hr, www.np-sjeverni-velebit.hr 
Tablica 2. Klasifikacija kopnenih prometnica u Velebitskom podgorju

\begin{tabular}{|c|c|c|c|c|}
\hline \multirow{2}{*}{$\begin{array}{ll}\text { A. } & \text { RAZVRSTANE } \\
& \text { PROMETNICE }\end{array}$} & \multicolumn{4}{|c|}{ B. NERAZVRSTANE PROMETNICE } \\
\hline & 1) ceste & 2) putovi & 3) vlake & 4) staze \\
\hline $\begin{array}{l}\text { 1. Državne ceste (DC) } \\
\text { 2. Županijske ceste (ŽC) } \\
\text { 3. Lokalne ceste (LC) }\end{array}$ & $\begin{array}{l}\text { - pristupne } \\
\text { (razvodne) } \\
\text { - šumske ceste } \\
\text { - ostale }\end{array}$ & $\begin{array}{l}\text { - do naselja } \\
\text { - šumski } \\
\text { - karavanski } \\
\text { (godišnje } \\
\text { migracije) }\end{array}$ & $\begin{array}{l}\text { - šumske } \\
\text { - ostale vlake }\end{array}$ & $\begin{array}{l}\text { - ophodarske } \\
\text { (šumarske, } \\
\text { gospodarske) } \\
\text { - planinarske } \\
\text { - ostale staze } \\
\text { (povijesne, } \\
\text { sportske, } \\
\text { hodočasničke) }\end{array}$ \\
\hline
\end{tabular}

Konjskog itd. U red pristupa do lučica na moru idu oni do Lukova, D. Klade, Kalići/Bačvica, Lomivrat itd. Pristupe do nekih drugih važnijih odredišta čine slične nerazvrstane prometnice (Zavratnica, Žrnovnica, Spasovac, Oštarijska vrata i sl.). Oblikovni elementi trase i poprečnog presjeka pristupnih prometnica su šaroliki i promjenjivi su od slučaja do slučaja. U pravilu bi to trebale biti dvosmjerne ceste širine kolnika oko 2x2,75 m (jednotračne 1x4,50 m ali s ugibalištima), no pojavljuju se i one sa skrominijm širinama te posebno one $\mathrm{s}$ vrlo strmim uzdužnim nagibima ( $\mathrm{s} \geq 15 \%$ ).

\section{Revalorizacija sekundarnih prometnica}

Potreba određenog razvrstavanja mreže sekundarnih prometnica proizlazi iz više razloga. Uzevši u obzir da su javne ceste razvrstane po konvencijama koje propisuju HR- i EU-normativi, preostaje da se još jednom razmotre razlozi i dobrobiti za kreiranjem pragmatičke skale nazivlja unutar podskupa nerazvrstanih cesta. Činjenica je, naime, da se iste (ili slične) staze ili putovi različito nazivaju u sklopu NP/PP Velebit, u turističkim pisanim vodičima, a posebno u usporedbi sa sličnom terminologijom u inozemstvu (npr. A, I, SLO, D, CH...).

Tako su poučne staze iz fundusa NP Sjeverni Velebit predočene na zanimljiv način: ${ }^{10}$

- Trag čovika, na starim stočarskim putovima

- Staza zviri, povezuje ulaz Siču i planinarski dom Zavižan

- Premužićeva staza, duljine 57 km i s 26 poučnih ploča

- Staza Botaničkog vrta, povodom 40. g. (1967.-2007. g.)

${ }^{10}$ www.velebit.hr, www.np-sjeverni-velebit.hr 
Predlaganje jedinstvenog/standardiziranog nazivlja neophodno je da se obradi i zaključi ono najbitnije: koje prometnice i na koji način ih podržati da posluže novoj razvojnoj svrsi. Opći izgled mreže predočen je grafički:

Iz navedenog prikaza mogu se izlučiti mnoge atribucije i detaljnija svojstva pojedinih vrsti prometnica, a ovdje će se istaći one koje su posebno vrijedne sa stajališta održivog razvoja i života u osjetljivom području. Pri ovome se sekundarne prometnice mogu analizirati unutar dvije markantnije grupacije:

- Povijesno - turističke ceste (c),

- Putovi i staze (s).

\section{Povijesno - turističke ceste (c)}

U ovoj grupaciji treba razlikovati ceste koje su "preživjele" sva povijesna i gospodarska vrjednovanja i danas su u punoj upotrebi, a one koje su ostale izvan prometa i u sebi nose povijesno - turistički potencijal.

U prvu podgrupu može se svrstati cesta D-23 od Senja prema Žutoj Lokvi/ unutrašnjoj Lici, te cestu D-25 od Karlobaga prema Gospiću i cestu D-27 od Maslenice prema Gračacu.

Drugoj podgrupi pripadaju ceste Sv. Juraj - Krasno - Otočac (Kosinj), Jablanac - V. Alan (1406 m n.v.) - Kosinj/Perušić, te povijesno eksponirana "Majstorska cesta" Zaton Obrovački - Marune - M. Alan (1044 m n.v.) -Tulove grede - Sv. Rok. Pri tome treba istaći da je cesta Sv. Juraj - Otočac još uvijek prometno aktualna, a druge dvije ceste su manje-više izvan uporabe.

Cesta Jablanac/Stinica - V. Alan - Štirovača $(32 \mathrm{~km})$ završena je 1876. godine, dakle iz vremena je izrazita otvaranja Velebita za veliku eksploataciju i izvoz drvne mase. Osim navedenog značaja, ovaj pravac je bio od velike važnosti u komunikaciji između Podgorja i Like, s ograncima prema Gospiću i Perušiću. Ovaj cestovni pravac bio je osnova za procvat "kirijašenja", tj. suvremenijeg prijevoza drva s Velebita, što je evoluiralo od korištenja vlâka do ceste i na kraju do žičare za Stinicu (Sl. 2).

Cesta Obrovac - M. Alan (1044 m n.v.) - Sv. Rok - Stara pošta (41 km) izgrađena je u vremenu 1825.-1832. godine i predstavljala je ključnu spojnicu između Like i Sjeverne Dalmacije, barem do izvedbe suvremene ceste Obrovac - Prezid - Gračac $(25 \mathrm{~km}, 1913)$ te posebno autoceste A1 (dionica Sv. Rok Maslenica, L-30 km, 2004. g.), Sl. 3.

Prvospomenuta Majstorska cesta s makadamskom podlogom iz 1832. godine nije danas u izrazitijoj prometnoj funkciji iz više razloga (minirano područje, rasterećenje od dviju drugih prometnica i sl.), a njezine prometno- 


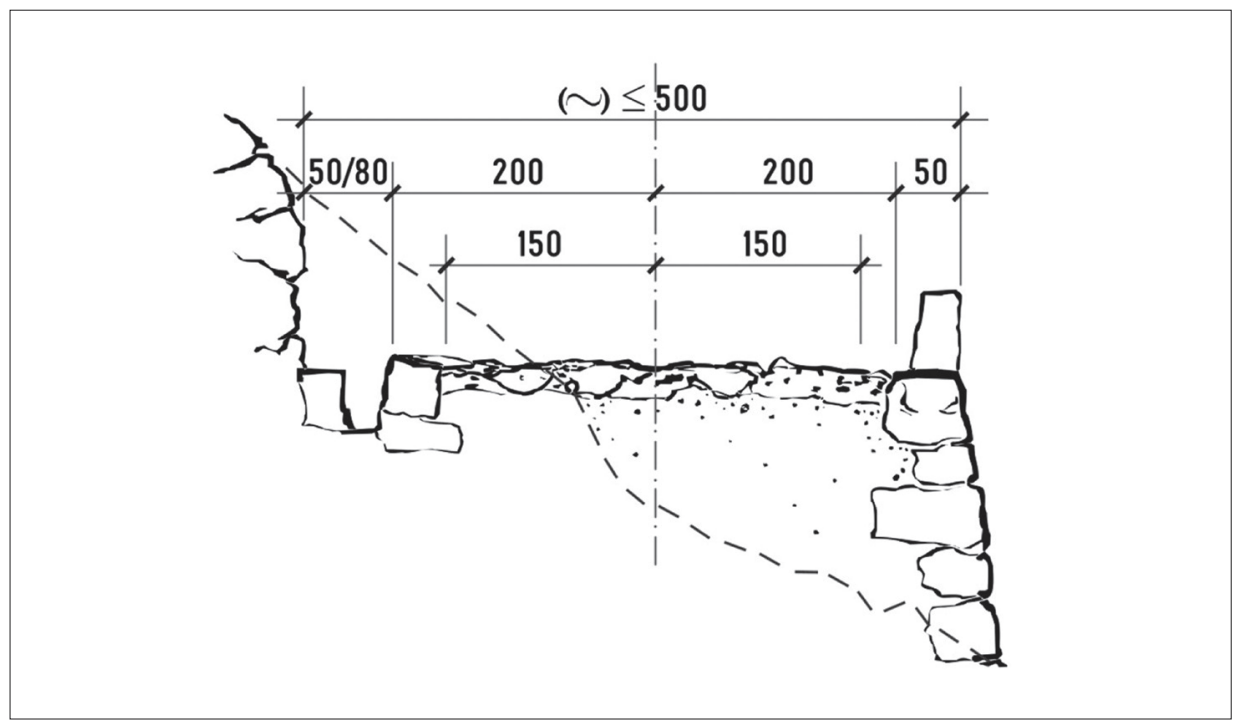

S1. 2. Povijesna cesta Jablanac - V. Alan - Štirovača (skica poprečnog presjeka autora iz 1997. g.)

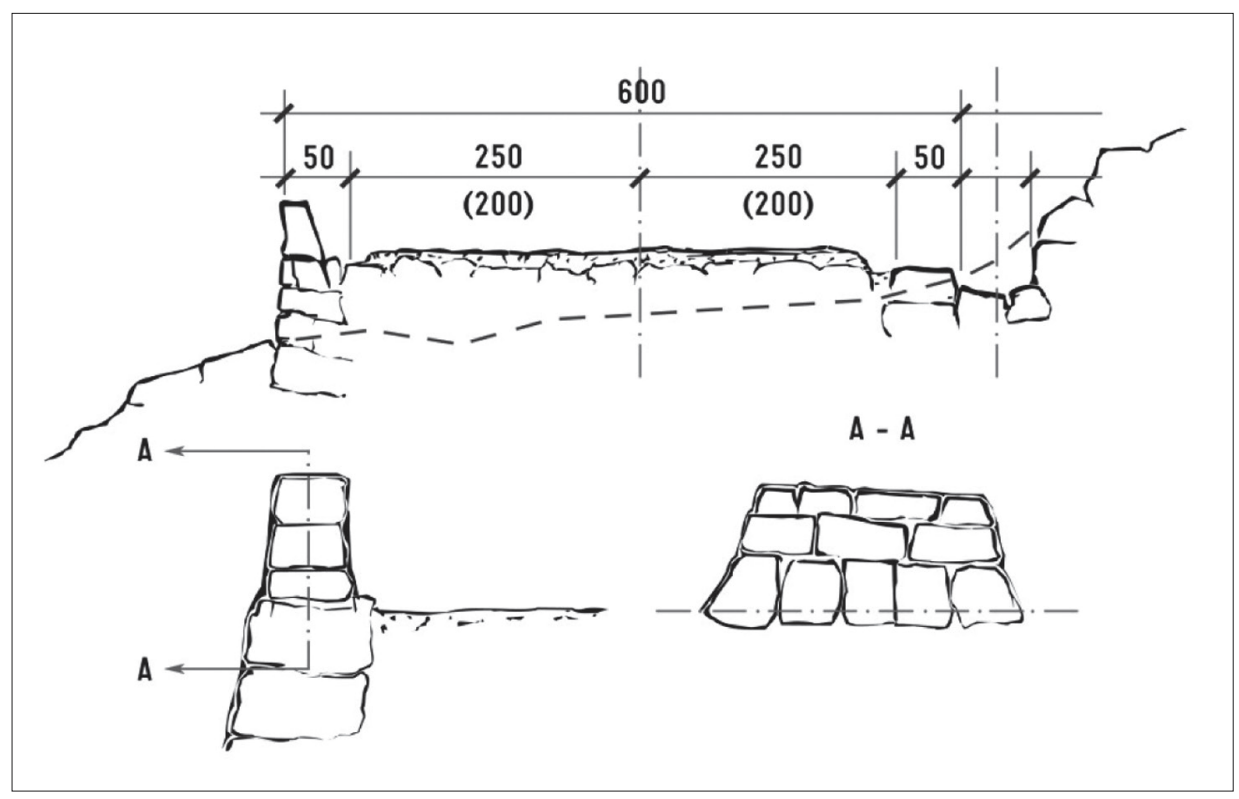

S1. 3. Poprečni presjek Majstorske ceste Obrovac - Sv. Rok (skica autora iz 1997. godine) 
tehničke vrijednosti, prateće građevine i neponovljiva ljepota okoliša odredile su je u red prvih povijesno-turističkih cesta u nas ${ }^{11}$.

- Fragmenti drugih povijesnih cesta, kao što su:

- Kraći odsječci ceste Sv. Juraj - Oltare (1010 m n.v.)

- Cesta Karlobag - Oštarijska vrata (927 m n.v.) - Baške Oštarije - Brušane

- Potezi trase starih cesta - Karoline, Jozefine itd.

Za ilustraciju navode se primjeri povijesnih cesta koje bi se moglo razraditi investicijsko-razvojnim projektima. Sadržaj i razrada u ovakvim elaboratima uobičajeni su u postupcima utvrđivanja realnih ciljeva i mogućnosti, odnosno za osiguravanjem financijske podrške.

Mnoge natuknice iz slijedećih primjera dviju cesta dane su za segment trase s kolnikom bez postupaka "modernizacije".

Cesta Jablanac/Stinica - Bileni - Dundović Podi - V. Alan (1406 m n.v.) Štirovača - Pazarišta (c)

- Analiza zatečena stanja

- Opis cestovnog tijela (kolnik, kolobrani, usjeci/nasipi, rubne ploče, elementi odvodnje, potporni zidovi, jače deformacije od prometa i sl.) te opis cestovnih građevina i okoliša

- Potrebni popravci

Stavke popravaka predvidjeti na temelju registriranih šteta, a treba ih grupirati po stručnoj srodnosti:

- zadržati položaj trase u doslovnom smislu, što se odnosi na sve tlocrtne i visinske elemente te sve sastavnice poprečnog presjeka ceste

- izvornom tehnikom treba rehabilitirati odnosno obnoviti cjelokupnu cestu

- zastor sačuvati i obnoviti u izvornom izgledu i tehničkom skladu (barem na oglednoj dionici)

- ugibališta predvidjeti na razmacima od oko $500 \mathrm{~m}$.

- Projekt obnove ceste trebao bi voditi inicijativni odbor (iz lokalne uprave, mjesnog stanovništva, PP/NP Velebit, stručna i konzervatorska struka...), a financijsku podršku moglo bi se očekivati od šireg spektra kompetentnih i zainteresiranih (resorna ministarstva, županije i lokalna uprava, Rapska plovidba, privatne tvrstke, fondovi EU...).

\footnotetext{
${ }^{11}$ Popravak postojeće ceste RC-2820 od Obrovca do Sv. Roka u dužini 9 km, 1998.
} 
- Modalitet održavanja i upravljanja cestom u eksploataciji ovisit će o dogovorenoj projektno-financijskoj konstrukciji, odnosno o fazi i opsegu zahvata; u užem tehničkom pogledu problematizirat će se i usvojiti norme/ standardi redovitog i izvanrednog održavanja za dosegnuti rang prometnice.

Potencijali ove ceste su mnogoznačni: to su prvenstveno povijesnoturističke, prometne i gospodarske vrijednosti, ali isto tako neke nove, npr. oživljavanje ambijentalnih vrjednota duž trase, od primorskog ugođaja do velebitskih naselja i rubnih područja Like.

\section{Majstorska cesta Obrovac - Podprag - M. Alan (1044 m n.v.) - Sv. Rok $\left(c_{2}\right)^{12}$}

Izvedba ove ceste (1827-1832 g.) pod nadzorom majora Kajetana Knežića koincidirala je s vremenom pripajanja Dalmacije carskoj Austriji, a zbog svojih tehničkih vrijednosti i razvoja trase zaslužila je naziv završnog majstorskog djela (das Meisterwerk - cehovski naziv uzornog rada). Cesta je priznati spomenik graditeljske baštine.

U trajanju od skoro 200 godina, cesta je doživjela najtežu degradaciju i propadanja od početka Domovinskog rata kad je obustavljen promet i kada je minirana u svom središnjem dijelu (ovaj dioje izbjegao nesmotrenu "modernizaciju" odnosno grubo asfaltiranje). Godine 1997-1998. provedeni su terenski očevidi, procjena potrebnih zahvata i mogući investitori, pa se prenose osnovni podatci:

\section{- Stanje ceste}

Konstatira se presvlačenje asfaltom oko 1970. g. na dijelu od Obrovca dio ceste D27 (Gračac - Maslenica) te od Sv. Roka do ispod M. Alana; dodatna modernizacija provedena je do 2000 g. od ceste D27 do južnog portala tunela Sv. Rok.

- Utvrđena je velika degradacija kolnika, te ogoljenost rubnog dijela s rubnim pločama i kamenim kolobranima. Odvodni jarkovi su urušeni ili zatrpani naplavljenim drobljencem, učestalo su degradirani potporni zidovi i registrirani znatni pomaci rubnih ploča uslijed teških vozila.

\section{- Potrebni popravci}

Planirani zahvati proizlaze iz uočenih šteta te su osnova za procjenu potrebnih količina radova. Točne količine je potrebno savjesno i stručno procijeniti, uz konzultacije i upute mjerodavnih zaštitara spomenika kulture. Pri svim popravcima potrebno je koristiti autentične ili slične materijale (zidovi,

\footnotetext{
${ }^{12}$ Cesta je od Zemunika išla preko Smilčića, Karina i Obrovca, preko Zrmanje i penjala se uz Velibit preko Podpraga i Malog Alana, prešla u Liku do Svetog Roka prema Gospiću.
} 
kolobrani, jarkovi...), a zastor kolnika izvesti u izvornoj tehnici, s eventualnim korištenjem prozirnog veznog sredstva. Ovisno o tehnološkim svojstvima i jediničnoj cijeni posebnog veznog sredstva, procijenjeni su troškovi popravaka u iznosu od 420 tisuća $\mathrm{kn} / \mathrm{km}^{13}$.

- Provedba projekta obnove trebala bi se provesti od državnih/županijskih cesta, uz suradnju spomenutih službi i uz institucije javnih škola građevinske, geotehničke i geodetske struke. Financijska konstrukcija bi se mogla ojačati EU fondovima, za što se treba pripremiti odgovarajuća dokumentacija i postupci.

- Održavanje i upravljanje obnovljene ceste trebalo bi se odvijati u duhu standardiziranih postupaka, uvažavajući sve specifičnosti povijesno vrijedne građevine.

Potencijali ove ceste su veoma veliki. Tu su prirodne ljepote okoliša (Tulove grede, Marune, crkva sv. Franje u Podpragu, Ćelavac, Sv. Rok...) i zasebno vrijedne znamenitosti vezane uz samu trasu i izgled ceste. Uz laki putnički promet, svi su preduvjeti za biciklističke izazove (tracking, rekreacijske ture) te pješačko-turistički promet i sportska događanja.

\section{Putovi i staze (s)}

Putovi i vlake (kao šumske primitivnije prometnice) izvorno su služile zaprežnom prometu, a staze za prolaz ljudi i stoke.

Između ranije spomenutih prometnica (poglavlje 1,2) mogu se spomenuti neke karakteristične:

- Gornji Kosinj - Mirovo - Stinička draga - Stinica,

- Štirovača - Ljuljevačko bilo - Rakovica/Jablanac,

- Rizvanuša - Mali stolac - Kovačica/Devčić Draga,

- Borovac - Padež - Klepina duliba,

- Blatina - Jasenova kosa - Alaginac - Baške Oštarije.

Staze datiraju uglavnom iz vremena gušće naseljenosti planinskog prostora i intezivnijeg kretanja od mora do planina. Mnoge od tih staza danas se koriste kao planinske, turističke ili staze za neke druge namjene.

- Planinarske staze danas već čine posebnu mrežu na cijelom prostoru Velebita, osobito unutar NP i PP Velebita [17]. Od svih njih uvijek treba istaći Premužićevu stazu uzduž Velebitskog bila $(\mathrm{L}=57 \mathrm{~km}, 26$ poučnih ploča) između Zavižana i Baških Oštarija. Staze su širine š $\geq 1,20 \mathrm{~m}$ i

\footnotetext{
${ }^{13}$ Popravak postojeće ceste RC-2820 od Obrovca do Sv. Roka u dužini 9 km, 1998.
} 


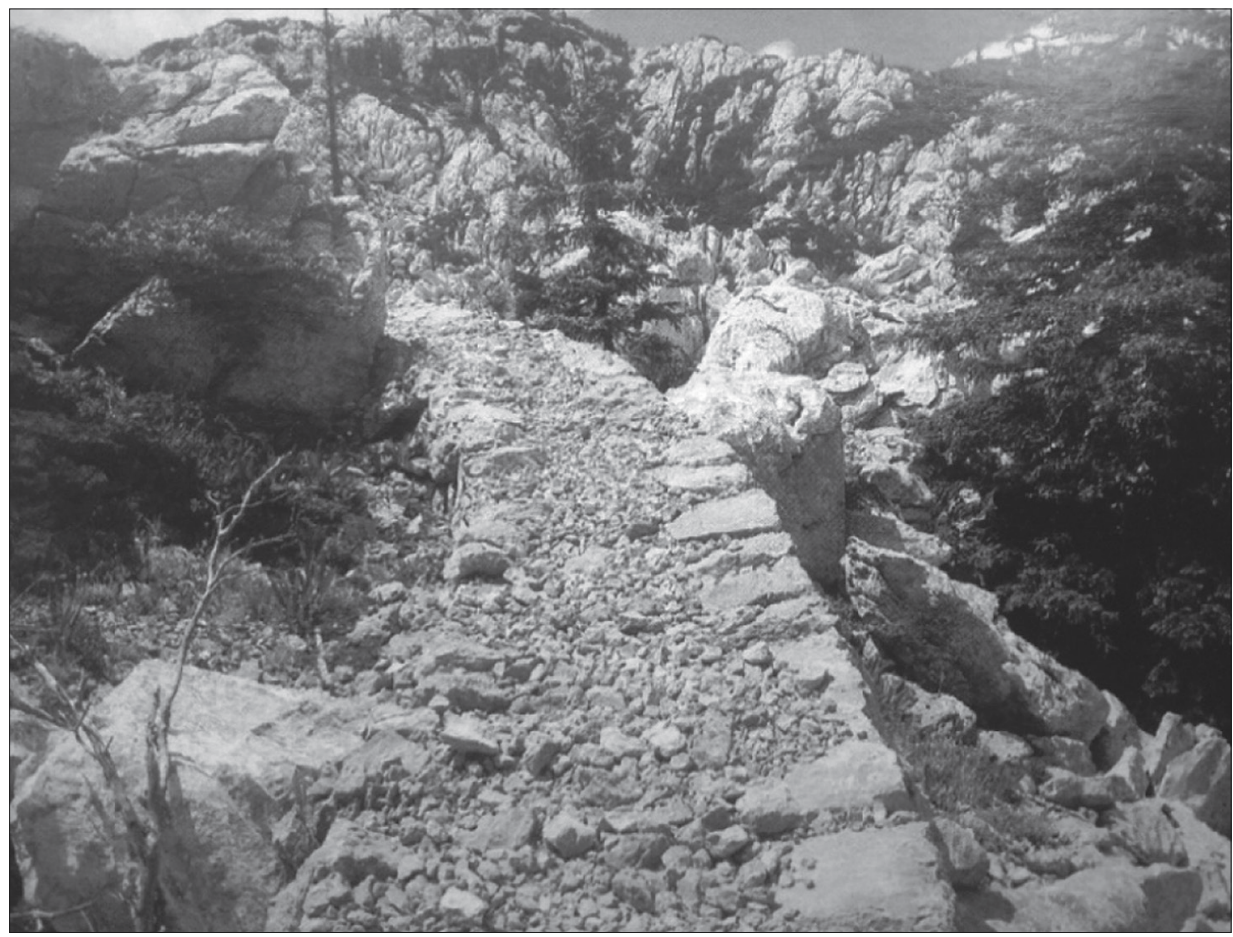

S1. 4. Primjer uređene pješačke staze ${ }^{14}$

s uzdužnim nagibom primjerenim za sve uzraste korisnika ( $u \leq 15 \%$ ). Najveća gustoća planinarskih staza je uz veće prirodne znamenitosti, vidikovce i planinske domove.

- Ophodarske staze/ceste vezane su uz šumske i vatrogasne nadzorne službe te uz odgovarajuće službe NP i NN Velebit. Izgrađene su i održavane u skladu s nadležnim pravilima i normativima.

- Turističke staze su u biti određene zahtjevima turističe klijentele, a vrlo često su iz vrste planinskih ili srodnih staza, s nešto lakšim nagibima i drugim elementima.

U narednim redcima predočena su stanja i potencijali putova i staza iznad Klade i Prizne kao i elementarna očekivanja od dorađenih staza u osmišljenim okvirima [mreža tradicijskih objekata, ponuda izvornih proizvoda i izleta, OPG (obiteljsko poljoprivredno gospodarstvo), poslovno povezivanje itd].

${ }^{14}$ A. ČAPLAR, 2014. 
Staza Donja Klada - Gornja Klada - Babrovača - ZavižanKrasno Polje ( $\left(s_{\text {) }}\right.$

- Postojeće stanje

Staza ima prirodno ishodište na morskoj obali u Donjoj Kladi odakle se uzdiže spojnom cestom na Jadransku magistralu (D8) na koti od oko $300 \mathrm{~m}$ n.v. u Gornjoj Kladi. Kraći tok trase preko Vukušića je u blažem usponu, zatim se završni dio postrmljuje i takav izbija na zaravan s Planinarskim domom Zavižan (oko $1600 \mathrm{~m}$ n.v.). Na ovom dijelu staza se križa s više prometnica: najprije sa stazom Trag čovika, Stazom zviri i ulaznom cestom od Babić Siče i s Premužićevom stazom iz smjera Baških Oštarija na jugoistoku. Od G. Klade do Planinarske kuće na Zavižanu ima oko 4-5 sati hoda.

\section{- Potrebne dorade}

Duž cijele trase potrebno je dotjerati stazu u pogledu poprečnog presjeka i uzdužnih nagiba, vertiklane signaliazcije i ostalih sastavnica standardiziranih za slične prometnice u ovom dijelu Velebita. Posebno treba obratiti pažnju na neophodne obavijesti i upozorenja za posjetitelje, te urediti odmorišta s panoramskim sadržajima i kvalitetnim vođenjem do pojedinih odredišta (slično na Premužićevoj stazi).

Najbitnije promjene i dorade očekuju se od nekoliko ambijentalnih lokaliteta (D. i G. Klada, Vukušići, Visibaba itd.) s osmišljenim sadržajem koje bi vodili autentični stanovnici (OPG, kuće s izvornim izgledom i ponudom usluga itd.).

Staza od Klade do Zavižana bi se mogla osmisliti kao cjelovit razvojni projekt, sa širim potencijalom (Lopar, Sv. Grgur/Goli otok, specifične ponude D. i G. Klade i Planinarskog doma Zavižan), ali i drugih izvora odnosno dotoka turista, sportskih natjecatelja i organiziranih grupa (s dobro osmišljenom pripremom i programima ponude).

\section{Staza Prizna - Mliništa - Šatorina - Štirovača,$\left(s_{2}\right)$}

- Postojeće stanje $\left(s_{2}\right)$

Prirodno ishodište je šire obalno područje Prizne (stara jezgra $s$ trajektnom lukom za otok Pag - Kovači, Brina, Sv. Ivan, Stara Prizna i novo naselje...) ali i stare naseobine kao Lomivrat, Čačići, Seline, Koromačina, Trolokve, Guste Zidine i Karaula. Prvi dio od obale do D8/magistrale je duljine oko 2,5 km i poklapa se s cestom pod prometom, a drugi dio je sastavljen od 
fragmenata starih staza iz vremena sezonskih seoba od kuća do stanova na Velebitu. Do odredišta u Mliništima i Šatorini može se svratiti u Panžinac, Prpić Lug i Kurtušu, a kod Meralovca i Mliništa može se izići na uređenu Premužićevu stazu. U daljem toku postoji mogućnost prolaska kroz Starčević Dolac i druge lokalitete, a preko Ledene vodice ili Klepine dulibe može se izići na povijesnu cestu Štirovača - Pazarišta.

\section{- Potrebne dorade}

U programu dorade neophodna stavka je definiranje staze (ili spleta staza) od Jadranske magistrale/D8, sa svim popravcima u pogledu poprečnog izgleda i uzdužnog toka trase te s izvedbom vidikovca i kvalitetne signalizacije.

Pri svim prilagodbama neophodno je predvidjeti osmišljenu mrežu "postaja" s ponudom tradicionalnog života (kućni interijeri, alati, gastroponuda...) s organiziranim izletima do planinarskih stanova i drugih odredišta. Trajektna povezanost s Pagom, prometna frekventnost Magistrale, Park prirode Velebit i Lika okvir su za optimizam.

Projekt oživljavanja ove staze ustvari je projekt vraćanja života u ovo područje uz pomoć nasljeđenih povijesno-tradicijskih potencijala. Realno je i uputno da ovakve projekte prepoznaju poslovno talentirani ljudi, ali bismo preporučili da to budu pojedinci iz ovih krajeva.

\section{Zaključak}

Opisana je povijesna pozadina izgradnje i stanje mreže kopnenih prometnica u području između Velebita i Jadrana. Relevantni podatci, između ostaloga, potvrđuju činjenicu da je vitalna prometnica uz planinski masiv u pravilu bila s ličke strane Velebita.

Cilj predmetnog rada bio je u prepoznavanju i analizi tradicijskih/ životvornih prometnica, koje bi se mogle pridružiti grupi manjih projekata $\mathrm{s}$ potencijalima za više razine turizma i gospodarstva u cjelini.

$\mathrm{S}$ tim u vezi trebalo je detektirati stanje i potencijale autentičnih prometnica u Podgorju i Velebitu te predložiti razvrstanost mreže sekundarnih prometnica. Nomenklatura bi u širem smislu trebala biti usklađena i zajednička s ostalima koje ovdje egzistiraju (javne ceste, šumske prometnice, prometnice u Parku prirode Velebit...).

U svim planerskim i projektnim postupcima treba se rukovoditi $\mathrm{s}$ relevantnim mjerilima, koje odrađuju kulturno - spomenički i javni interesi te interesi domicilnog stanovništva i manjih zajednica na terenu. 
Posljedično na polazne korake, trebalo bi provesti konkretne radnje i razrade po uzorku ili određenom modelu, odnosno trebalo bi modelirati projekte s nositeljima i postupcima u realizaciji najpotentnijih prometnica, npr:

a) povijesno - turističke ceste (preko M. Alana i preko V. Alana)

b) tradicionalno migracijske ceste (npr. Prizna - Mliništa, Klada Visibaba)

c) posebno razraditi model za povlačenje sredstava iz fondova EU, odnosno dugoročnije iz naših izvora.

Problematizirano je također stanje služnosti i sigurnosti prometa na Jadranskoj turističkoj cesti D8 od Senja do Maslenice. Najnovija istraživanja ukazuju na loše stanje i na neodgodivu modernizaciju cijele dužoblane ceste, te na izvedbu obilaznice oko Sv. Jurja i Karlobaga. Potrebno je također modernizirati poveznice do manjih naselja na obali kao što su Lukovo, D. Klada, Starigrad, Bačvice itd.

\section{Literatura}

Šime BALEN, Jablanac (1179-1979) - uz 800. obljetnicu, Zagreb, 1979.

Alan ČAPLAR, Velebit-planinski vodič, Zagreb, 2014.

Alan ČAPLAR, Planinarski vodič po Hrvatskoj, Meridijani, Samobor, 2009.

Lara ČERNICKI - Stašo FORENBAHER, Starim cestama preko Velebita, Zagreb, 2016.

Lara ČERNICKI - Stašo FORENBAHER, Starim cestama do mora, Libricon, Zagreb, 2012.

Dragutin FELETAR, Kratki pregled razvoja povijesnih cesta na području Hrvatske, Ceste i mostovi, 49, 9-10, 98-107, Zagreb, 2003.

Dragutin FELETAR, Skok preko gorskog praga, Ceste i mostovi, 49/7-8, 102-106, Zagreb, 2003.

Petar FELETAR, Hrvatske povijesne ceste - Karolina, Jozefina, Lujzijana, Meridijani, Zagreb, 2016.

Matija GLAD, Via Josephina (1770-2007), makadamska cesta koja je približila Karlovac i Senj, Ceste i mostovi, 53, 3, 100-107, Zagreb, 2007.

Matija GLAD, Ceste Primorsko-goranske županije, povijest cestovnog graditeljstva $i$ održavanja, Društvo za ceste Via Vita, Ceste Rijeka, Naklada Kvarner, Rijeka, 2014.

Matija GLAD - Petra IVANIŠ, Via Carolina Augusta (1726.-2007.), Ceste i mostovi, 53/2, Hrvatsko društvo za ceste Via Vita, Zagreb, 104-109, 2007. 
Ivan LEGAC, Podvelebitska cestovna mreža (radni materijal), podprojekti: Obilaznica Sv. Jurja i Karlobaga, MPPV-Zagreb, 1995-1997.

Ivan LEGAC - Vjeko DORIĆ, Jadranska autocesta, Zbornik Hrvatske autoceste, Zagreb, 1998.

Ana LEMIĆ, Sela i stanovi na Velebitu. Svjedočanstva života od nastanka do nestanka, Gospić, 2013.

Ive MAŽURAN, Karlobag (1251-2001), monografija, Zagreb, 2001.

Dane PEJNOVIĆ - Branko VUJASINOVIĆ, Prometna valorizacija Velebita - povijesno geografski prikaz, Geografski glasnik, Zagreb, 1998.

Dane PEJNOVIĆ, Utjecaj prometnog sustava na socijalno-gospodarski razvoj $i$ organizaciju prostora Ličke regije, Hrvatski geografski glasnik, 55, Hrvatsko geografsko društvo, Zagreb, 157-181, 1993.

Dane PEJNOVIĆ, Srednja Lika - socijalnogeografska transformacija, Gospić, 1995.

Dane PEJNOVIĆ, Geografske osnove identiteta Like, Identitet Like: korijeni i razvitak, knjiga 1, Zagreb-Gospić, 45-84, 2009.

Drago PIČMAN, Šumske prometnice (udžbenik), Zagreb, 2007.

Željko POLJAK, Hrvatske planine, vodič s atlasom, Zagreb, 1996.

Popravak postojeće ceste RC-2820 od Obrovca do Sv. Roka u dužini $9 \mathrm{~km}$ (idejno riješenje, interno HC/M. Ereš i I. Legac), Zagreb, 1998.

Strategija razvitka cestovne mrě̌e u Republici Hrvatskoj, nacrt, Ministarstvo razvitka i obnove i Ministarstvo pomorstva, prometa i veza, Zagreb, 1996.

Dane ŠIKIĆ i dr, Tehnički uvjeti za gospodarske ceste, Zagreb, 1989.

Izvori

www.velebit.hr, www.np-sjeverni-velebit.hr

info.hps.hr/putovi 


\section{THE REVALORISATION OF SECONDARY ROADS IN VELEBIT PODGORJE}

\section{Summary}

The general condition of the transport infrastructure and traffic in the area of Velebit Podgorje is shown, with a reference to the times of the emergence of the historical roads, routes and paths. It is indicated in the more important potentials of secondary roads, which should be evaluated in the sense of the general offer of Velebit (tourism, sport, educational component...), but also with regard to the revival of traditional aspects of real life "in situ". Following on these kinds of assumptions, the modelling of projects could be carried out for the cases of neglected historical roads (e.g. the road Jablanac - V. Alan - Štirovača, the Majstorska cesta Obrovac - M. Alan - Sveti Rok) and the projects of seasonal-migratory paths from the littoral settlements to the summer dwellings on the more fertile Velebit localities (e.g. the path Klada - Babrovača - Zavižan, Prizna - Mliništa - Šatorina, Cesarica - Radlovac - Dabrovi and alike). Along with the subsystem of secondary roads also problematized is the condition of the access and safety of traffic on the main Adriatic highway - the magistrale - tourist road the D- 8 as the basic coastal connection of Podgorje. The bad condition and the need of the very urgent modernisation the whole of the road from Senj to Maslenica is pointed out, as well as the construction of a bypass around Sveti Juraj and Karlobag. The connections to the smaller settlements along the coast (Lukovo, Donja Klada, Starigrad etc.) should also be modernised.

Keywords: historical roads, Velebit Podgorje, migratory paths, tourist offer, sustainable development 